\title{
Hubungan antara Pengetahuan dan Pendidikan Ibu dengan Pemberian ASI Eksklusif di Desa Kedungrejo Kecamatan Waru Kabupaten Sidoarjo
}

\author{
Correlation between Knowledge, Education and Exclusive Breastfeeding \\ among Mothers in Kedungrejo Village, Waru Sub-district, Sidoarjo District
}

\author{
Diah Ayu Pitaloka*1, Rumaidhil Abrory ${ }^{2}$, Ayu Deni Pramita ${ }^{3}$
}

\begin{abstract}
ABSTRAK
Latar Belakang: ASI Eksklusif adalah memberi Air Susu Ibu secara Ekslusif tanpa ada makanan atau minuman tambahan lainnya yang mulai dilakukan saat bayi baru lahir sampai bayi berumur 6 bulan. Data dari Profil Kesehatan Indonesia tahun 2014 menyatakan bahwa bayi yang menerima ASI Eksklusif di Indonesia hanya sebesar $41,67 \%$.

Tujuan: Mengetahui pengetahuan ibu dan pendidikan ibu hubungannya dengan pemberian ASI Eksklusif di desa Kedung rejo, Kecamatan Waru, Kabupaten Sidoarjo.

Metode: Penelitian ini adalah penelitian deskriptif analitik menggunakan desain cross sectional. Populasi penelitian ini merupakan ibu yang memiliki bayi usia 6-12 bulan di Desa Kedungrejo Kecamatan Waru Kabupaten Sidoarjo yang dipilih secara simple random sampling sebanyak 31 orang. Data kemudian dikumpulkan dan diuji dengan menggunakan uji Fisher's Excact.

Hasil: Hasil menunjukkan bahwa prevalensi pemberian ASI Ekslusif di Desa Kedungrejo Kecamatan Waru Kabupaten yaitu hanya 29\%. Hasil uji dengan menggunakan Fisher's Exact menunjukkan bahwa pengetahuan dan pendidikan ibu tidak berhubungan terhadap pemberian ASI Ekslusif pada bayi usia 6-12 bulan.
\end{abstract}

Kesimpulan: Tidak ada hubungan yang signifikan antara pengetahuan ibu, pendidikan dan praktik pemberian ASI eksklusif di kalangan ibu.

Kata kunci: pengetahuan ibu, pendidikan ibu, ASI Ekslusif, bayi usia 6-12 bulan

\begin{abstract}
Background: Exclusive breastfeeding is a breastfeeding exclusively without any food or other additional beverages starting from newborns to 6 months old baby. Data from Indonesia Health Profile of 2014 states that infants receiving Exclusive Breast Milk in Indonesia only reach 41.67\%.

Objectives: To analyze the relationship between maternal knowledge, education, and exclusive breastfeeding among mothers in the village of Kedung Rejo, Waru Sub-district, Sidoarjo District.

Methods: This research was descriptive analytic study using cross sectional design. The population of this study was mothers who has infants aged 6-12 months in Kedungrejo Village Waru Sub-district Sidoarjo District. Sample was selected using simple random sampling technique involving 31 people. Data analysis was tested using Fisher's exact test.

Results: The results showed that the prevalence of exclusive breastfeeding in Kedungrejo Village, Waru Sub-district was 29\%. The results of tests using Fisher's Exact showed that mother's knowledge and education were not related to exclusive breastfeeding in infants aged 6-12 months.

Conclusion: There was no significant association between maternal knowledge, education and exclusive breastfeeding practices among mothers.
\end{abstract}


Keywords: mother's knowledge, mother's education, exclusive breastfeeding, infants aged 6-12 months

*Koresponden:

diahayujitu@gmail.com

1,2,3Wijaya Kusuma University Surabaya, Jawa Timur, Indonesia

\section{PENDAHULUAN}

Air Susu Ibu (ASI) merupakan sumber makanan paling sempurna untuk bayi karena memiliki kandungan berbagai zat dan antibodi yang penting untuk pertumbuhan dan perkembangan bayi. ${ }^{1}$ Bayi yang menerima ASI eksklusif telah terbukti lebih cerdas dan sulit terserang peyakit. ${ }^{1}$ Seiring pertumbuhannya, asupan gizi yang dibutuhkan bayi bertambah dan saluran cerna bayi semakin berkembang maka diperlukan Makanan Pendamping ASI (MP-ASI) agar bayi bisa tumbuh dan berkembang secara maksimal. ${ }^{1}$

Rendahnya persentase ASI eksklusif pada bayi 0-6 bulan, meningkatkan angka kejadian beberapa penyakit seperti ISPA dan diare. Sedikitnya prevalensi dan semakin singkatnya lama penyusuan meningkatkan resiko jumlah morbiditas dan mortalitas pada bayi di sejumlah negara-negara berkembang, terutama penyakit ISPA dan diare. Serta ketidaktaatan dalam memberikan ASI eksklusif bisa menyebabkan gangguan gizi. Pada tahun 2003 didapatkan kurang lebih 6,7 juta balita $(27,3 \%)$ mengalami kurang gizi, 5 juta diantaranya mengalami gizi buruk. ${ }^{2}$ Kemudian anemia gizi diderita oleh 8,1 juta balita. ${ }^{2}$

Data dari WHO menunjukkan bahwa setiap tahunnya terdapat 132.000 bayi telah meninggal sebelum usia mereka mencapai 1 tahun. ${ }^{3}$ Pemberian ASI (Air Susu Ibu) secara eksklusif di Indonesia pada nyatanya sangat mencemaskan. Angka Kematian Bayi (AKB) di Indonesia telah mencapai 35 per 1000 kelahiran hidup (SDKI 2002-2003) setidaknya masih di atas negara Malaysia, Thailand, Filipina, dan Singapura. Kurang lebih $40 \%$ mortalitas bayi terjadi di bulan pertama kehidupannya. Data survey Sosial Ekonomi Nasional (Susenas) tahun 2007 menyatakan ASI eksklusif yang diberikan pada bayi kelompok 0 mencapai $76,4 \%$, pada saat berumur 1 bulan mencapai $85,5 \%$, saat 2 bulan $72,9 \%$, kemudian usia 3 bulan mencapai $61,7 \%, 4$ bulan mencapai $47,5 \%$ dan saat telah mencapai usia 6 bulan prosentase didapatkan $62,2 \% .{ }^{4}$ Di Kabupaten Sidoarjo cakupan bayi yang mendapat ASI eksklusif tahun 2011 sebesar 7,1 \% dari 1.637 bayi. Sedangkan data di Desa Kedungrejo cakupan bayi yang mendapat ASI Eksklusif hanya mencapai 6,9\% (28 dari 403 bayi) Padahal target nasional untuk cakupan ASI Eksklusif adalah $70 \%$ sehingga masih dibawah target. $^{5}$

Berdasarkan penelitian-penelitian tentang ASI Eksklusif yang terus berkembang, WHO (World Health Organization) dan IDAI (Ikatan Dokter Anak Indonesia) telah memberikan kode etik yang memberikan aturan agar setiap bayi wajib diberikan ASI eksklusif (ASI tanpa selingan atau tambahan apapun, meski itu air putih) sampai usia minimal mencapai 6 bulan. Jika telah mencapai usia 6 bulan, bayi secara bertahap diberikan MP-ASI (makanan pendamping ASI) yaitu berupa, buah, nasi tim, bubur susu dan lain-lain. Pemerintah juga baru memberikan keputusan Menkes (Menteri Kesehatan) dalam meneruskan kode etik yang telah diluncurkan WHO. Keputusan baru ini mengatur cara pemberian ASI eksklusif (Permenkes nomor 450/Menkes/SK/IV/2004). Pemerintah Indonesia juga mengatur cara pemberian makanan pendamping ASI (MPASI) yang ditulis pada pemenkes nomor 237/1997. Harus diingat MP-ASI bukan merupakan makan pengganti ASI. ${ }^{6}$

Menurut Baskoro faktor sosiokultural ibu paling berpengaruh terhadap pemberian ASI antara lain umur, pendidikan, pengetahuan, sikap dan pekerjaan ibu. ${ }^{7}$ Namun dalam penelitian Widiyanto faktor pengetahuan dan pendidikan ibu yang paling terlihat berpengaruh dalam pemberian $\mathrm{ASI}^{8}{ }^{8}$ Dalam penelitiannya, ${ }^{8}$ pengetahuan dan 
pendidikan ibu memberikan korelasi bermakna terhadap pemberian ASI eksklusif. Berdasarkan hal di atas maka tujuan penelitian ini adalah untuk mengetahui pengetahuan ibu dan pendidikan ibu hubungannya dengan pemberian ASI Eksklusif di desa Kedung rejo, Kecamatan Waru, Kabupaten Sidoarjo.

\section{METODE}

Penelitian ini berjenis observasional dan bersifat deskriptif analitik. Sedangkan ditinjau dari waktu pelaksanaannya penelitian ini adalah penelitian cross sectional yaitu pengumpulan data variable bebas dan variable terikatnya dilakukan satu kali dalam kurun waktu tertentu.

Populasi penelitian ini merupakan ibu yang mempunyai bayi dengan usia 0-12 bulan yang berada di desa Kedung Rejo Kecamatan Waru Kabupaten Sidoarjo. Diketahui sejumlah ibu yang memiliki bayi di desa Kedungrejo, Kecamatan Waru Kabupaten Sidoarjo, berjumlah 116 orang. Kemudian dilakukan skrining menggunakan kriteria inklusi, ibu yang memiliki bayi berusia 6-12 bulan, maka didapatkan sub populasi dari penelitian ini adalah sebanyak 78 responden.

Sampel dari penelitian merupakan sejumlah yang kemudian diambil dari keseluruhan objek-objek yang diteliti, sehingga dianggap menggambarkan kondisi seluruh populasi. ${ }^{9}$ Sampel dari penelitian ini merupakan ibu yang mempunyai bayi berumur 6-12 bulan yang berada di desa Kedungrejo, Kecamatan Waru, Kabupaten Sidoarjo.

Kriteria inklusi dari subjek penelitian: Bayi berumur 6-12 bulan, riwayat mendapat atau tidak mendapat ASI eksklusif, rutin ke posyandu setiap bulannya, dan ibu bersedia diwawancarai. Kriteria eksklusi: bayi tidak rutin ke posyandu, dan ibu bayi tidak bersedia untuk diwawancarai

Sampel minimal yang diperlukan berdasarkan rumus mencari jumlah minimal dengan rumus Lameshow. ${ }^{10}$

$$
n=\frac{Z^{2}{ }_{1-} \alpha_{12} p(1-p) N}{d^{2}(N-1)+Z^{2}{ }_{1-}{ }^{2}{ }_{12} p(1-p)}
$$

Keterangan :

$\mathrm{N}=$ jumlah sampel minimal yang diperlukan

$Z^{2}{ }_{1-\alpha / 2}=$ derajat kepercayaan

$\mathrm{P} \quad=$ proporsi anak yang diberi ASI secara eksklusif

$\mathrm{q} \quad=1-\mathrm{p}$ (proporsi anak yang tidak diberi ASI secara eksklusif)

$\mathrm{d}=$ = limit dari error atau presisi absolute

Jadi besar sampel ibu yang mempunyai bayi berusia $6-12$ bulan sebesar $n=19$ orang, namun dalam penelitian ini menggunakan sampel sejumlah 31 orang. Pengambilan sampel ini menggunakan cara tehnik Simple Random Sampling, pengambilan sampel dilakukan dengan acak yaitu menggunakan metode lotre. Responden dalam penelitian ini adalah ibu dari bayi terpilih sebagai sampel yaitu 31 orang ibu yang memiliki bayi berumur 6-12 bulan yang berada di desa Kedungrejo , Kecamatan Waru, Kabupaten Sidoarjo. Penelitian ini dilaksanakan pada tanggal 18 Agustus sampai dengan 13 September 2014.

Pengetahuan ibu yang dimaksud dalam penelitan ini adalah kemampuan ibu dalam menjawab pertanyaan pada kuesioner tentang manfaat dan pentingnya ASI Eksklusif dimana tingkat pengetahuan tersebut akan dikategorikan dengan diatas rata-rata dan dibawah rata-rata. Ibu dengan penilaian diatas rata-rata adalah ibu yang mampu menjawab pertanyaan dengan jawaban benar $7-10$ point, sedangkan dengan jawaban benar $<7$ dikategorikan dibawah rata-rata. Distribusi tingkat pendidikan responden diklasifikasikan menjadi 2 jenis tingkat pendidikan, yaitu rendah dan tinggi. Pendidikan lbu yang telah bersekolah sampai SMP diklasifikasikan Pendidikan rendah, sedangkan pendidikan Ibu diatas SMP diklasifikasikan Pendidikan tinggi.

\section{HASIL}

Distribusi pengetahuan ibu di puskesmas medaeng disajikan dalam tabel 1 . Dari tabel 1 menunjukkan sebagian besar 
tingkat pengetahuan ibu masih rendah yaitu sebanyak $54,80 \%$ dari 31 responden yang ada. Sedangkan yang tingkat pengetahuannya dibawah rata-rata hanya mecapai $45,20 \%$ saja.

Tabel 1. Pengetahuan Ibu di Puskesmas Medaeng, Kecamatan Waru, Kabupaten Sidoarjo

\begin{tabular}{lcc}
\hline Pengetahuan & $\mathbf{n}$ & $\mathbf{\%}$ \\
\hline Diatas rata-rata & 14 & 45,20 \\
Dibawah rata-rata & 17 & 54,80 \\
\hline Total & 31 & 100,00 \\
\hline
\end{tabular}

Distribusi tingkat pendidikan ibu di puskesmas medaeng disajikan dalam table 2 . Dari tabel 2 menunjukkan bahwa semua responden pernah menjalani pendidikan disekolah dan sebagian besar responden berpendidikan tinggi yaitu sebesar $51,60 \%$ sedangkan responden yang berpendidikan rendah hanya sebesar $48,40 \%$.

Tabel 2. Pendidikan lbu di Puskesmas Medaeng, Kecamatan Waru, Kabupaten Sidoarjo

\begin{tabular}{lcc}
\hline Pendidikan & $\mathbf{n}$ & $\mathbf{\%}$ \\
\hline Rendah & 15 & 48,40 \\
Tinggi & 16 & 51,60 \\
\hline Total & 31 & 100,00 \\
\hline
\end{tabular}

Tabel 3. Pemberian ASI Eksklusif di Puskesmas Medaeng, Kecamatan Waru, Kabupaten Sidoarjo

\begin{tabular}{lcc}
\hline $\begin{array}{l}\text { Pemberian ASI } \\
\text { Eksklusif }\end{array}$ & $\mathbf{n}$ & $\%$ \\
\hline $\begin{array}{l}\text { Tidak diberi ASI } \\
\text { Eksklusif }\end{array}$ & 22 & 71,00 \\
Diberi ASI Eksklusif & 9 & 29,00 \\
\hline Total & 31 & 100,00 \\
\hline
\end{tabular}

Distribusi pemberian ASI eksklusif pada bayi usia 6-12 bulan responden akan disajikan dalam tabel 3. Dari tabel 3 dapat disimpulkan bahwa terdapat responden yang tidak memberi ASI eksklusif dengan jumlah ibu 22 orang (71\%). Sedangkan terdapat 9 responden (29\%) yang mengaku memberikan ASI eksklusif.

\section{Hubungan Pengetahuan Ibu dengan Pemberian ASI Eksklusif}

Distribusi pengetahuan ibu pada penelitian ini akan disajikan dalam tabel 4 . Tabel 4 menunjukkan bahwa dari hasil penelitan sebagian besar ibu yang memilih ASI Eksklusif untuk bayinya adalah ibu yang mempunyai pengetahuan lebih dari rata-rata, yaitu sebanyak $66,70 \%$ dari 9 responden.

Hasil uji statistik dengan Fisher's Exact Test menunjukan bahwa nilai signifikansinya 0.233 (sig > 0,05). Ini menunjukan bahwa pengetahuan ibu tidak berhubungan dengan Pemberian ASI Eksklusif pada bayi 6-12 bulan. Hal ini tidak sesuai dengan penelitian yang dilakukan Visyara dan Bahri yang menyatakan bahwa ada hubungan antara pengetahuan ibu dengan pemberian ASI eksklusif. ${ }^{11,12}$

Hasil pengujian dengan menggunakan Odds Ratio menunjukkan ternyata ibu yang pengetahuannya di bawah rata-rata cenderung memberikan ASI Ekeklusif pada bayi 6-12 bulan sebanyak 3,500 kali dibanding dengan ibu yang pengetahuanya di atas ratarata.

Informasi yang diberikan baik oleh keluarga maupun petugas kesehatan mengenai ASI eksklusif dapat berhubungan dengan pengetahuan ibu. ${ }^{13}$ Bila informasi yang diberikan kurang tepat, maka informasi yang diterima ibu juga akan salah. ${ }^{13} \mathrm{Hal}$ ini menyebabkan pengetahuan ibu masih sangat rendah, karena informasi yang diberikan tentang ASI eksklusif masih kurang. ${ }^{13}$

Pada tingkat pengetahuan, sebagian besar responden berpengetahuan kurang dari rata-rata yaitu $17,6 \%$ responden memberikan ASI eksklusif, dan responden berpengetahuan diatas rata-rata mencapai $42,9 \%$ responden. Penyuluhan, siaran dari radio, televisi atau pun video, artikel dari majalah dan surat kabar bisa memberikan pengetahuan pada ibu, namun tidak selalu bisa mengubah perilaku dan kebiasaan ibu. ${ }^{13}$ 
DOI : 10.2473/amnt.v2i3.2018.265-270

Tabel 4. Hubungan Pengetahuan Ibu dan Pemberian ASI Eksklusif di Puskesmas Medaeng, Kecamatan Waru, Kabupaten Sidoarjo

\begin{tabular}{lccccc}
\hline \multirow{2}{*}{ Pengetahuan Ibu } & \multicolumn{3}{c}{ Pemberian ASI Eksklusif } & \multicolumn{2}{c}{ P value $>\mathbf{0 , 0 5}$} \\
\cline { 2 - 5 } & \multicolumn{1}{c}{ Tidak Diberi ASI Eksklusif } & \multicolumn{2}{c}{ Diberi ASI Eksklusif } & & \\
\cline { 2 - 5 } & $\mathbf{( n )}$ & $\mathbf{( \% )}$ & $\mathbf{( n )}$ & $\mathbf{( \% )}$ & \multirow{2}{*}{0.233} \\
\hline Kurang dari rata-rata & 14 & 63,60 & 3 & 33,30 & \\
Lebih dari rata-rata & 8 & 36,40 & 6 & 66,70 \\
\hline Total & 22 & 100,00 & 9 & 100,00 & \\
\hline
\end{tabular}

\section{Hubungan Pendidikan Ibu dengan Pemberian ASI Eksklusif}

Distribusi pendidikan ibu yang berhubungan dengan pemberian ASI Eksklusif pada bayi usia 6-12 bulan disajikan dalam tabel 5. Tabel 5 menunjukkan bahwa dari hasil penelitan, sebanyak $66,70 \%$ dari 9 ibu yang memberikan ASI Eksklusif pada bayi 6-12 bulan adalah ibu yang berpendidikan rendah.

Hasil pengujian statistik menggunakan Fisher's Exact Test menunjukkan bahwa nilai signifikansinya 0.252 (sig > 0,05). Hal ini menunjukkan bahwa pendidikan ibu tidak berhubungan dengan pemberian ASI Eksklusif pada bayi 6-12 bulan. Namun hasil penelitian Anggrita ternyata menunjukkan bahwa juga tidak ada hubungan $(p>0,330)$ antara pendidikan ibu dengan pemberian ASI eksklusif. ${ }^{14}$

Hasil pengujian dengan menggunakan Odds Ratio menunjukkan ternyata ibu yang berpendidikan rendah cenderung memberikan ASI Ekeklusif pada bayi 6-12 bulan sebanyak 0,346 kali dibanding dengan ibu yang berpendidikan tinggi.

Menurut Notoatmodjo tingkat pendidikan merupakan jenjang pendidikan yang dicapai paling akhir. ${ }^{9}$ Tingkat pendidikan merupakan suatu standar yang menunjukkan seseorang dapat berperilaku dengan cara yang ilmiah. Seseorang dengan tingkat pendidikan rendah akan sulit memahami pesan atau informasi yang tersampaikan. Dari hasil penelitian diketahui bahwa sebagian besar responden yang berpendidikan rendah berasal dari lulusan SD dan SMP yaitu 40,0\% responden sedangkan tingkat pendidikan tinggi yaitu SMA dan Sarjana menunjukkan $18,8 \%$ responden.

Meski teori di atas menjelaskan bahwa ibu yang tingkat pendidikan tinggi atau baik dapat lebih mudah menerima segala informasi. Penelitian Novita menyebutkan semakin tinggi tingkat pendidikan ibu, maka semakin tinggi jumlah ibu yang tidak memberikan ASI pada bayinya. ${ }^{15}$

Hal ini sejalan dengan hasil penelitian ini. Soenardi menyebutkan kenaikan tingkat partisipasi wanita dalam pendidikan dan adanya emansipasi dalam segala bidang kerja dan kebutuhan masyarakat menyebabkan turunnya kesediaan menyusui dan lamanya menyusui. ${ }^{16}$

Ibu yang bekerja mengalami kesulitan seperti cuti melahirkan yang terlalu singkat dan tidak adanya ruang laktasi juga sangat mempengaruhi pemberian ASI eksklusif pada anaknya. ${ }^{16}$ lbu bekerja yang menyusui sebenarnya tidak perlu berhenti menyusui anaknya, sebaiknya ibu bekerja harus tetap memberi ASI Ekslusif kepada bayinya hingga umur 6 bulan. Banyak kemudahan yang terdapat di PP no 33 th 2012 sehingga ibu dapat memberikan ASI eksklusif meski sedang bekerja. ${ }^{17}$

Tabel 5. Hubungan Pendidikan Ibu dan Pemberian ASI Eksklusif di Puskesmas Medaeng, Kecamatan Waru, Kabupaten Sidoarjo

\begin{tabular}{|c|c|c|c|c|c|}
\hline \multirow{3}{*}{ Pendidikan Ibu } & \multicolumn{4}{|c|}{ Pemberian ASI Eksklusif } & \multirow[t]{3}{*}{$P$ value $>0.05$} \\
\hline & \multicolumn{2}{|c|}{ Tidak Diberi ASI Eksklusif } & \multicolumn{2}{|c|}{ Diberi ASI Eksklusif } & \\
\hline & (n) & $(\%)$ & (n) & $(\%)$ & \\
\hline Rendah & 9 & 40,90 & 6 & 66,70 & \multirow[t]{3}{*}{0.252} \\
\hline Tinggi & 13 & 59,10 & 3 & 33,30 & \\
\hline Total & 22 & 100,00 & 9 & 100,00 & \\
\hline
\end{tabular}




\section{KESIMPULAN}

Dapat disimpulkan bahwa tidak ada hubungan yang signifikan antara pengetahuan dan pendidikan ibu terhadap pemberian ASI eksklusif di Desa Kedungrejo, Kecamatan Waru, Kabupaten Sidoarjo.

\section{ACKNOWLEDGEMENT}

Peneliti mengucapkan terimakasih kepada seluruh responden, yaitu para ibu yang mempunyai bayi dengan usia 0-12 bulan yang berada di desa Kedung Rejo Kecamatan Waru Kabupaten Sidoarjo, telah meluangkan waktu dan bekerjasama mewujudkan penelitian ini terlaksana dengan baik dan sesuai harapan peneliti.

\section{REFERENSI}

1. Sutomo, B., Yanti, D. . Sajian Lezat Makanan Sehat Pendamping ASI. (Demedia, 2010).

2. Amiruddin, R. Status Gizi Ibu Hamil,Rokok dan Efeknya. (2007). Available at: https://www.google.co.id/url?sa=t\&rct $=j \& q=\&$ esrc $=s \&$ source $=w e b \& c d=7 \& c a d$ $=$ rja\&uact $=8 \&$ ved $=0$ CDOQFjAG \&url $=\mathrm{htt}$ p\%3A\%2F\%2Fdigilib.unimus.ac.id\%2Fdo wnload.php\%3Fid\%3D6287\&ei=ofryUDrA4GHuATfsIDABg\&usg=AFQjCNEWFF 6RAsmdhq25KEMgAkXt3RCY-

A\&bvm=bv.73231344,d.c2E. (Accessed: 19th August 2014)

3. World Health Organization (WHO). The physiological basis of breastfeeding: model chapter for medical students and allied health professionals. (2005).

4. Badan Pusat Statistika (BPS). Data Susenas 2004-2007 Mengenai Distribusi Pemberian ASI pada bayi 0-6 bulan di Indonesia. (2007).

5. Dinas Kesehatan Kabupaten Sidoarjo. Profil Kesehatan Kabupaten Sidoarjo Tahun 2011. (2011).

6. Prabantini, D. $A$ to $Z$ Makanan Pendamping ASI. (ANDI, 2010).
7. Baskoro, A. ASI: Panduan Praktis Ibu Menyusui. (Banyu Medika, 2008).

8. Widiyanto, S., Aviyanti, D.A., Merry, T. Hubungan Pendidikan dan Pengetahuan Ibu tentang ASI Eksklusif dengan Sikap terhadap Pemberian ASI Eksklusif Subur. J. Kedokt. Muhammadiyah 1, 2529 (2012).

9. Notoatmodjo, S. Metodologi Penelitian Kesehatan. (Rineka Cipta, 2005).

10. Lemeshow, S., Hosmer, D.W., Klar, J., Lwanga, S. . Besar Sampel dalam Penelitian Kesehatan. (Gajah Mada University Press, 1997).

11. Visyara, N.I., Sari, K., Marhaento, S. Beberapa Faktor Yang Berhubungan Dengan Pemberian MP-ASI Pada Bayi Usia 0-6 Bulan Di Bps Heni Suharni Desa Langensari Kecamatan Ungaran Barat. Kabupaten Semarang. (Ngudi Waluyo Ungaran, 2012).

12. Bahri, R. . Hubungan Pengetahuan dan Sikap Ibu dengan Pemberian MP-ASI di Kelurahan Pb. Selayang II Kecamatan Medan Selayang Tahun 2011. (Universitas Sumatera Utara, 2011).

13. Soetjiningsih. Skrinning Tumbuh Kembang Di Berbagai Tingkat Pelayanan Kesehatan. Disampaikan pada Simposium dan Pelatihan Deteksi Dini dan Intervensi Penyimpangan Tumbuh Kembang Anak. (EGC, 2006).

14. Anggrita, K. Hubungan Karakteristik Ibu Menyusui Terhadap Pemberian Asi Eksklusif Di Wilayah Kerja Puskesmas Medan Amplas Tahun 2009. (Universitas Sumatera Utara, 2009).

15. Novita, D. Hubungan karakteristik ibu, faktor pelayanan kesehatan, immediate breastfeeding dan pemberian kolostrum dengan pemberian ASI ekslusif di wilayah kerja puskesmas Pancoran Mas Depok tahu 2008. (Universitas Indonesia, 2008).

16. Soenardi, T. Gizi Seimbang Untuk Bayi \& Balita. (Prima Media Pustaka, 2006).

17. PERATURAN PEMERINTAH \& REPUBLIK INDONESIA. PEMBERIAN AIR SUSU IBU EKSKLUSIF. (2012). 